\title{
Dampak Perencanaan Perubahan Free Trade Zone Menjadi Kawasan Ekonomi Khusus Di Kota Batam
}

\author{
Alfiandri \\ Program Studi Ilmu Administrasi Negara \\ Fakultas IImu Sosial dan IImu Politik \\ Universitas Maritim Raja Ali Haji \\ alfiandrikepri@gmail.com \\ Mahadiansar \\ Magister Ilmu Administrasi Publik \\ Fakultas Ilmu Administrasi \\ Universitas Brawijaya \\ mahadiansar@student.ub.ac.id
}

\begin{abstract}
The emergence of organizational change and the transfer of authority resulted in adverse impacts on the Free Trade Zone in Batam City which led to leadership dualism between the Batam City Government and Batam Entrepreneurs Agency (BP) and the weakening of the global economy which affected one region in Batam City. The climate of investment in Batam City starting from the management services with FTZ is hampered making the government issue a policy of changing the status from FTZ to KEK (Special Economic Zones) led by Batam Wallikota. The purpose of this study is to look at the impact of changes in planning changes in FTZ organization to KEK. This research method uses literature study with library sources such as e-books, journals, websites, organizational reports and other documents both print and online that are relevant to data analysis techniques (content analysis). The results show that the change of FTZ into KEK does not significantly influence the development of investment both domestic and foreign entrepreneurs who invest their capital in Batam City. Researchers also found that SEZs have many different weaknesses from FTZ, which for this time local entrepreneurs in Batam City felt more disadvantaged than SEZs. It is expected that the government of Batam City will take a strategic step which is to collaborate between regional entrepreneurs and the central government in developing KEK that will impact the economy of Batam City.
\end{abstract}

Keywords: Organizational Change, Free Trade Zone, Special Economic Zones

\begin{abstract}
Abstrak
Munculnya perubahan organisasi serta pengalihan wewenang mengakibatkan dampak buruk terhadap Free Trade Zone di Kota Batam yang menyebabkan adanya dualisme kepemimpinan antara Pemerintah Kota (Pemko) Batam dan Badan Pengusaha (BP) Batam serta melemahnya perekonomian global yang berdampak ke daerah salah satunya di Kota Batam. Iiklim investasi di Kota
\end{abstract}


Batam dimulai dari pelayanan pengurusan dengan FTZ menjadi terhambat membuat pemerintah mengeluarkan kebijakan perubahan status dari FTZ ke KEK (Kawasan Ekonomi Khusus) yang dipimpin oleh Wallikota Batam. Tujuan dari penelitian ini ialah melihat dampak perubahan perencanaan perubahan organisasi FTZ ke KEK. Metode penelitian ini menggunakan studi kepustakaan dengan sumber-sumber pustaka seperti e-book, Journal, Website, Laporan Organisasi dan dokumen lainnya baik cetak maupun online yang relevan dengan teknik analisis data (content analysis). Hasil menunjukkan bahwasanya perubahan FTZ menjadi KEK tidak berpengaruh besar terhadap perkembangan investasi baik pengusaha dalam negeri maupun luar negeri yang menanamkan modalnya ke Kota Batam. Peneliti juga menemukan KEK memiliki banyak kelemahan berbeda dengan FTZ yang selama ini bagi pengusaha daerah Kota Batam lebih merasa diuntungkan dari pada KEK. Diharapkan pemerintah Kota Batam mengambil langkah yang strategis yaitu melakukan kolaborasi antara pengusaha daerah dan pemerintah pusat dalam mengembangkan KEK yang akan berdampak kepada perekonomian Kota Batam.

\section{Kata Kunci: Perubahan Organisasi, Free Trade Zone, Kawasan Ekonomi Khusus}

\section{Pendahuluan}

Secara umum munculnya Kawasan Perdagangan Bebas atau dikenal dengan Free Trade Zone yang disingkat dengan FTZ, merupakan sebuah kawasan perdagangan yang berada didalam pelabuhan strategis. Para peneliti dan pemerintah mencari alternatif skema dan pola pembangunan yang berkelanjutan guna meningkatkan perekonomian disektor perdagangan. Dalam bidang ilmu regional yang dimulai pada lima dekade yang lalu, konsep pertumbuhan yang muncul telah memperkenalkan fenomena multiplier effects dan trickling down. Ide ini telah diterjemahkan ke dalam berbagai konsep pembangunan, termasuk FTZ. Faktor-faktor penentu ialah memberikan kontribusi secara signifikan pada performa ekonomi dan spillover extend FTZ. Dengan menggunakan analisa statistik, dapat dilihat serta dikaji perbandingan antara faktor-faktor kompetitif dan performa ekonomi dari tiga FTZ di wilayah Asia, yaitu Indonesia, Filipina dan China.

Di Indonesia mengacu pada Undang-Undang Nomor 36 tahun 2000 tentang Kawasan Perdagangan Bebas dan Pelabuhan Bebas yang kemudian dirubah beberapa kali melalui PERPU, sehingga menjadi Undang-Undang Nomor 44 tahun 2007 melalui penghapusan bea dan cukai. Pemerintah memerintahkan beacukai memberlakukan produk sektor sebagai produksi lokal yang mana barang-barang tersebut dijual kedalam negeri, tujuannya 
agar dapat memformulasikan kebijakan yang berfungsi untuk menghilangkan, mengurangi segala hambatan perdagangan sehingga barang dapat didistribusikan dan diekspor tanpa ada tekanan dari berbagai pihak yang berlaku pada perdagangan internasional.

Dalam Undang-Undang Nomor 36 tahun 2000 pengganti UndangUndang Nomor 1 Tahun 2000 tentang Kawasan Perdagangan Bebas dan Pelabuhan Bebas yang mengatur tentang FTZ di Provinsi Kepulauan Riau menjelaskan bahwa Kawasan Perdagangan Bebas dan Pelabuhan Bebas Batam dilakukan kegiatan-kegiatan di bidang ekonomi, seperti sektor perdagangan, maritim, industri, perhubungan, perbankan, pariwisata dan bidang lainnya. Kolaborasi oleh Pemerintah pusat dan daerah dalam hal ini Provinsi KEPRI digunakan sebagai pijakan hukum untuk menyusun UndangUndang FTZ untuk Batam. Dalam menentukan faktor-faktor kompetitif, konsep Neo-klasik seperti local endowment, modal infrastruktur dan manusia, hingga pendekatan kelembagaan dengan indikator-indikator termasuk kebijakan pemerintah dapat menjangkau akses pasaran. Performa ekonomi FTZ bergantung pada kekonsistenan kebijakan pemerintah nasional dan daerah dengan adanya ketersediaan infrastruktur. Pada pelaksanaan FTZ tersebut, FTZ dikendalikan oleh Badan Perusahaan Batam (BP Batam) atau yang dikenal dengan Otorita Batam. hal ini menjadi berbagai konflik perkembangan FTZ.

Berkembangnya FTZ Kota Batam muncul tumpang tindih konflik kepentingan yang terjadi. konfik tersebut ialah dualism yaitu antara Pemerintah Kota (Pemkot) Batam dengan Badan Pengusahaan (BP) Batam. Terjadinya dualisme membuat para investor bingung mengurus administrasi misalnya untuk mengurus perizinan, maka investor harus melalui pemerintah Kota Batam dan juga BP Batam. Seharusnya perizinan cukup dilakukan hanya jalur satu pintu dalam pelayanan. Saat ini pemerintah berupaya untuk mencari alternatif lain untuk mengatasi konflik tersebut. Salah satu pilihan yang ada ialah dengan memberikan kepada satu pengelola atau tetap mempertahankan kedua pihak agar memperjelas kewenangan serta skema tugas dan fungsi. Sehingga meningkatkannya perekonomian Kota Batam yang lebih maksimal investor asing daam menanamkan modalnya termasuk juga mengatasi masalah-masalah yang ada. 
Konflik dualisme menyebabkan terhambatnya investasi yang tentunya akan berdampak pada perkembangan FTZ Batam. Pertumbuhan ekonomi yang cenderung melambat juga mempengaruhi proses investasi dikawasan tersebut. Kondisi ini sangat jelas membuat para investor tidak nyaman karena harus berurusan dengan kedua institusi tersebut. Potensi investasi Kota Batam masih tinggi, salah satu perusahaan Singapura yang menyatakan niatnya berinvestasi disektor galangan kapal. Pemerintah akan membuat kebijakan baru untuk menghentikan dualisme pengelolaan FTZ Batam. Pemerintah Pusat memperkirakan negara kehilangan penerimaan pajak sebesar Rp20 triliun pertahun akibat tumpang tindih kepemimpinan dalam mengelola FTZ Batam. Dualisme tersebut muncul karena selama ini FTZ Batam dikelola oleh Badan Pengelola (BP) Batam terpisah dengan wewenang Pemerintah Kota Batam. Secara umum kondisi perkembangan kawasan pelabuhan dan FTZ Batam saat ini tidak sesuai dengan harapan.

Pemerintah memutuskan Badan Pengusaha (BP) Batam akan dibubarkan untuk menghilangkan dualisme kewenangan yang ada di wilayah tersebut. Selanjutnya kewenangan yang ada dibawah BP Batam akan dipindahkan kepada pemeritah Kota Batam yang di ketua oeh Wali Kota sesuai dengan instruksi Presiden Joko Widodo. Berdasarkan data dari kementerian perekonomian pada tahun 2017 hingga 2019, dari sisi Produk Domestik regional Bruto (PDRB) kota batam, pertumbuhannya terus menurun hanya mencapai $2,19 \%$ pada tahun 2017 . Kemudian melambat drastis dari capaian tahun sebelumnya mencapai 5,43\%. Bahkan pada tahun 2013 pertumbuhan ekonomi batam bisa mencapai 7\% lebih. Kemunduran ini menjadi jelas catatan merah BP Batam sebelum dibubarkan.

Garfik 1.

Pertumbuhan Ekonomi dan Pertumbuhan Industri Kota Batam di kelola BP Batam dengan Status Free Trade Zone (FTZ) 2013-2017.

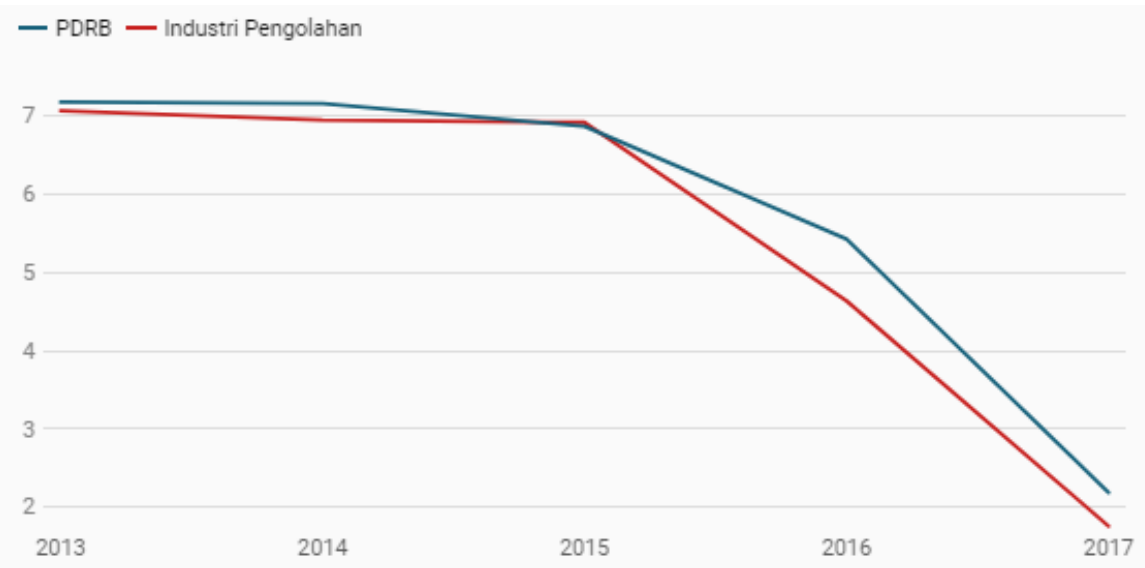


296 | Alfiandri, Mahadiansar. Dampak Perencanaan Perubahan ...

Sumber : BPS Kota Batam 2019

Melambatnya pertumbuhan ekonomi Kota Batam tidak lepas dari pertumbuhan sektor industri pengolahan yang loyo. Pada tahun lalu, pertumbuhannya hanya mencapai 1,76\%. Padahal di tahun 2016 masih membukukan pertumbuhan sebesar 4,64\%, sedangkan di tahun 2013 bisa mencapai 7,07\%. Akhirnya keputusan Presiden Jokowi untuk membubarkan BP Batam nampaknya sudah tepat. Sudah tiba waktunya menyelamatkan "Singapura-nya Indonesia" yang semakin jauh tertinggal.

Proses pembubaran dan pengalihan akan diselesaikan sesuai ketentuan hukum. Langkah ini berarti kewenangan pemerintah pusat lewat BP Batam akan dialihkan ke Pemerintah Kota Batam sepenuhnya. Pemerintah menginginkan Batam memiliki daya saing ekonomi yang tinggi hingga daya tarik bagi investor maka pemerintah pusat melakukan Perubahan Free Trade Zone (FTZ) ke Kawasan Ekonomi Khusus (KEK) berkaitan dengan perizinan, kepastian hukum bagi investor, khususnya infrastruktur, masalah pelabuhan, dan lainnya. Kehadiran KEK bisa menyeesaikan permasalahan ini, investor akan lebih tertarik investasi modal di Kota Batam. KEK merupakan kawasan dengan batas tertentu yang tercangkup dalam daerah atau wilayah untuk menyelenggarakan fungsi perekonomian dan memperoleh fasilitas tertentu seperti insentif yang ditawarkan. KEK di Indonesia mulai diatur sejak tahun 2009, yang merupakan pengembangan dari berbagai jenis kawasan ekonomi di periode-periode sebelumnya. Urgency dari tulisan ini adalah melihat sejauh mana dampak perencanaan perubahan pengelolaan organisasi dari FTZ menjadi KEK yang di kelola langsung oleh pemerintah kota batam.

\section{Tinjauan Pustaka}

\section{Perubahan Organisasi}

Perubahan Organisasi adalah suatu proses dimana organisasi tersebut berpindah dari keadaannya yang sekarang menuju ke masa depan yang diinginkan untuk meningkatkan efektifitas organisasinya. Tujuannya adalah untuk mencari cara baru atau memperbaiki dalam menggunakan resources 
dan capabilities dengan tujuan untuk meningkatkan kemampuan organisasi dalam menciptakan nilai dan meningkatkan hasil yang diinginkan kepada stakeholders.

(David, 2005) perubahan yang terjadi dalam organisasi seringkali membawa dampak yang selalu tidak menguntungkan kemudian (Abrahamson, 2000) mempertegaskan perubahan juga akan menimbulkan kejadian "dramatis" yang harus dihadapi oleh semua anggota organisasi yang terlibat secara aktif. (Porras \& Robertson, 1992) kebijakan perubahan organisasi yang dilakukan oleh beberapa organisasi hanya memberikan manfaat positif bagi organisasi sebesar 38\%. Meskipun perubahan organisasi tidak langsung memberikan manfaat yang besar bagi kemajuan organisasi, namun beberapa praktisi tetap meyakini tentang pentingnya suatu organisasi untuk melakukan perubahan.

(Daft \& Daft, 2010) menyatakan zaman akan terus menerus berubah secara konstan, suatu organisasi harus menyesuaikan dengan segala perubahan untuk dapat bertahan tergantung lingkungan disekitarnya. Adapun faktor yang mempengaruhi perubahan tersebut terdiri dari :

1. Kekuatan Persaingan (Competitive Forces); Setiap organisasi akan berusaha keras untuk mencapai keuntungan dari persaingan. Persaingan menjadi pemicu untuk melakukan perubahan dikarenakan apabila organisasi tersebut tidak dapat melebihi pesaingnya dalam efisiensi, kualitas atau kemampuan untuk melakukan inovasi pada produk dan jasa, maka organisasi tersebut tidak akan bertahan.

2. Ekonomi. Politik, dan Kekuatan Global; Ekonomi, politik, dan kekuatan global secara terus menerus mempengaruhi organisasi dan memaksa mereka untuk bagaimana dan di mana harus menghasilkan barang dan jasa. Perserikatan ekonomi dan politik antar negara menjadi suatu kekuatan yang penting untuk perubahan. Tidak ada suatu organisasi yang mampu mengabaikan dampak dari ekonomi global dan kekuatan politik terhadap aktivitasnya.

3. Kekuatan Demografi dan Sosial (Demography and Social Forces); Perubahan dalam komposisi dari kekuatan pekerja dan terus meningkatnya keanekaragaman karyawan, hal ini mengenalkan pada organisasi banyaknya peluang dan tantangan. Perubahan dalam karakteristik demografis dari kekuatan pekerja memaksa para manajer untuk merubah 
gaya mereka dalam mengatur karyawan dan belajar bagaimana cara memahami, mengawasi dan memotivasi dengan setiap anggota yang berbeda secara efektif. Banyak perusahaan membantu para pekerja mereka untuk memahami akan adanya perubahan teknologi yang terus berkembang dengan menyediakan dukungan dalam mengedepankan pelatihan dan pendidikan.

4. Kekuatan Etika (Ethical Forces) sama pentingnya bagi suatu organisasi dalam mengambil tindakan untuk berubah sebagai tanggapan atas tuntutan dalam perubahan demografis dan sosial untuk kearah perilaku perusahaan yang lebih jujur dan bertanggung jawab. Banyak organisasi membutuhkan perubahan untuk mengizinkan para stakeholder dan para pekerja disemua tingkatan untuk melaporkan perilaku yang tidak pantas, sehingga suatu organisasi dapat dengan segera menyingkirkan perilaku buruk dan melindungi kepentingan umum bagi para pelanggan hingga anggotanya

\section{Free Trade Zone (FTZ)}

Kawasan perdagangan bebas atau biasa disebut dengan Free Trade Zone merupakan zona ekonomi yang pada umumnya mempunyai definisi yang berbeda-beda, sebab banyaknya perspektif yang berbeda yang di kemukakan beberapa para ahli tentang Free Trade Zone. Free Trade Zone memiliki konsep teoritis yang membentuk sistem jalur perdagangan bersifat internasional yang di permudahkan segala hambatan yang menjadi ketentuan pemerintah daerah ataupun pemerintah pusat dalam rangka mempererat diplomasi kedua negara. Dipermudahnya sistem perdagangan dengan alasan oleh tariff barriers maupun non tariff barriers.

Valentine \& Park, $(2005,5: 6)$ berdasarkan dari Karakteristik Utama FTZ dari berbagai literatur yang ada terbagi atas 4 definisi yaitu :

1. (Kusago \& Tzannatos, 1998) FTZ memiliki karakteristik kawasan industri yang ditetapkan oleh kekuasaan pemerintahan sebagai kawasan perdagangan oleh sebuah negara dimana perusahaan asing melakukan aktivitas produksi yang bersifat ekspor, mendapat keuntungan dari jumlah pendapatan dari kebijakan yang ada.

2. (Madani, 1999) FTZ merupakan wilayah yang dibatasi secara tertutup dengan wilayah ditetapkan oleh negara dan terletak pada lokasi geografis 
sehingga menguntungkan investor sesuai dengan pelaksanaan perdagangan dimana operasional berbasis industri pada prisip beacukai dan fiscal segregation.

3. (Internasional Labour Organization, 1998) FTZ merupakan bagian kawasan industri dengan insentif khusus yang dibentuk demi menarik investor asing, dimana bahan impor mengalami beberapa tingkat proses sebelum diekspor kembali

4. (World Bank, 1992) kawasan industri yang mengkhususkan dirinya dalam nilai jual untuk ekspor dan menawarkan kepada para yang mempunyai kekuasaan kepada kondisi perdagangan bebas dan lingkungan yang berpodaman pada keinginan tersendiri.

Berdasarkan definisi diatas, karakteristik umum dari konsep FTZ dapat di uraikan yang pertama memiliki infrastruktur bisnis di atas rata-rata. Di dalam kawasan industri khusus, para investor diberikan infrastruktur dan layanan berkualitas dibandingkan dengan layanan pada umumnya oleh pemerintah daerah maupun pusat seperti wewenang atas tanah, ruang kantor, layanan untuk logistik, layanan bisnis dan fasilitas lainnya.

Yang kedua peraturan para pembisnis yang lebih fleksibel. Layanan pengawasan disederhanakan oleh penyelenggara serta penerapan dalam implementasi investasi. Lanjut dengan undang-undang ketenagakerjaan dan bisnis terkait lainnya secara umumnya lebih mudah dibandingkan dengan beberapa peraturan yang berlaku untuk para pembisnis yang menjadi kawasan investasi.

Yang ketiga yaitu kawasan lepas pantai. Posisi FTZ dipilih sebagai kawasan untuk aktivitas bisnis investasi yang bergerak dikawasan lepas pantai, jauh dari pasar dimana produk yang telah jadi akan dijual untuk mencari basis nilai jual barang yang siap jadi serta berbiaya rendah atau lebih rendah. Kemudian fokus pada ekspor dimana perusahaan yang berlokasi didalam FTZ akan memberikan dampak atau menghasilkan terutama secara eksklusif untuk pasar asing maupun pasar di luar negeri. Dan yang terakhir yaitu adanya insentif yang menarik. Komponen utama dari konsep FTZ adalah insentif yang ditawarkan kepada investor asing dengan syarat

1. Pengurangan atau pembebasan bea masuk yang tidak terbatas dari bea impor bahan baku, memasukan antara dan barang modal yang digunakan dalam produksi produk yang diekspor. 
2. Bebas biaya pajak penjualan untuk produk yang akan diekspor pada semua barang dan jasa yang dibeli akan digunakan dalam negeri serta produksinya.

3. Bebas pajak dengan potongan harga dalam pengurangan tarif pajak atas pendapatan pada laba perusahaan, terkait dengan kinerja ekspor perusahaan ataupun persentase ekspor dalam jumlah produksi

(Thurston, 1996) FTZ secara umum dapat di definiskan bahwa Free Trade Zone yaitu "An Free Trade Zone is in essence, a taxfree enclave and not consideres part of the country as far as import regulations are concerned. When an item leaves an free trade zone and is officially imported into the host country of the Free Trade Zone, all duties and regulation are imposed."

\section{Kawasan Ekonomi Khusus (KEK)}

Pembuat kebijakan tidak hanya menghadapi tantangan didaerah untuk membuat KEK sehingga berhasil, namun kebutuhan untuk fokus terhadap strategis yang memadai, model regulasi dan tata kelola pengelolaan hingga alat atau media promosi investasi (Pramoda \& Apriliani, 2016). KEK di wilayah yang dibatasi secara geografis dimana pemerintah memfasilitasi kegiatan industri melalui insentif fiskal dan peraturan yang didukungan dengan pembangunan infrastruktur dan pada umumnya banyak digunakan sebagian besar negara banyak negara maju dibandingkan negara berkembang. Meskipun tantangan KEK dengan tidak sesuainya ekspektasi yang di inginkan, terutama gagal menarik investasi secara besar-besaran yang berpengaruh dengan target menghasilkan dampak ekonomi diluar kemampuan pengusaha (Moberg, 2015; Aggarwal, 2007). KEK hadir disebabkan pemerintah semakin mempunyai keinginan bersaing untuk kegiatan industri skala internasional. Selain itu tantangan baru yang ditimbulkan oleh dampak akan pembangunan berkelanjutan, perbaikan industri baru akan merubah pola kebijakan pada produksi internasional.

(Farole \& Akinci, 2011) KEK telah menjadi alat yang kuat untuk menarik investasi asing, mempromosikan pertumbuhan yang berorientasi ekspor, dan menghasilkan lapangan kerja; bagi banyak orang lain, hasilnya kurang menggembirakan. Sementara manfaat dan keterbatasan kawasan pasti akan terus diperdebatkan, yang jelas pembuat kebijakan semakin tertarik kepada investor sebagai instrumen perdagangan, investasi, industri, 
dan kebijakan wilayah. Laporan (United Nations Conference On Trade And Development, 2019) yang dirilis, kunci Keberhasilan KEK diantaranya

1. Fokus Pada Strategi; Ekonomi yang paling berhasil mencapai pengembangan industri yang cepat melalui penggunaan KEK menggarisbawahi bahwa KEK bukan hanya alat promosi investasi, tetapi terutama adalah alat kebijakan industri. Faktor penting yang mendorong keberhasilan KEK ini dan kontribusi mereka terhadap pembangunan ekonomi nasional.

2. Pengaturan Kerangka Kerja Tata Kelola; KEK sebagai wilayah dengan rezim yang menyimpang dari aturan nasional, tentu merupakan inisiatif publik. Namun demikian pengembangan, kepemilikan, dan pengelolaan KEK yang individu dapat memiliki katagori bersifat publik, swasta, atau kolaborasi.

3. Proposisi Nilai ; Kerangka hukum KEK hampir selalu mendefinisikan paket manfaat bagi investor di zona, khususnya pembebasan bea cukai, pajak, dan rezim peraturan nasional lainnya. Karena KEK semuanya berasal dari konsep zona bebas - bebas dari tarif, pajak, dan birokrasi - komponen dasar paket insentif sangat mirip di sebagian besar jenis zona dan sebagian besar wilayah geografis. Banyak penelitian mengidentifikasi penyediaan infrastruktur keras dan lunak di sekitar zona, ketersediaan keterampilan dan basis pemasok yang memadai, dan fasilitasi bisnis dan layanan bersama sebagai faktor penentu keberhasilan pengembangan dan dampak zona. Ini juga merupakan manfaat yang dapat lebih mudah mendukung upaya pengelompokan aktif dan spesialisasi di zona.

\section{Metode Penelitian}

Metode penelitian yang peneliti gunakan studi kepustakaan (library research), dengan melakukakan penelusuran terhadap beberapa sumbersumber pustaka seperti e-book, Journal, Website, Laporan Organisasi dan dokumen lainnya baik cetak maupun online yang relevan dengan topik yang sedang dikaji pada penelitian. Studi kepustakaan merupakan serangkaian aktivitas kegiatan yang berkenaan dengan metode pengumpulan data pustaka, membaca, dan mencatat serta mengelolah bahan penelitian (Zed, 2014). Pada penelitian ini menggunakan teknik pengumpulan data dokumentasi yang berasal dari berbagai reference jurnal bereputasi, e-book 
302 | Alfiandri, Mahadiansar. Dampak Perencanaan Perubahan ...

yang berhubungan dengan dampak perubahan organisasi. Adapun teknik analisis data pada penelitian ini yaitu content analysis.

\section{Pembahasan}

\section{Konflik Perubahan Status FTZ ke KEK Batam}

KEK dibatam mendapat banyak penolakan dari pengusaha kota batam yang menyatakan bahwsanya memiliki kerugian tidak berefek sama investasi. Asosiasi Pengusaha Indonesia (APINDO) Provinsi Kepulauan Riau telah melakukan pendalam bahwasanya KEK di Kota Batam akan menguntungkan bagi penguasa / rezim serta tidak mempunyai wewenang yang mengikat dan pada akhirnya gairah investasi dalam negeri akan cenderung menurun. KEK batam hanya di fokuskan ke beberapa wilayah berbeda dengan FTZ secara umum semua pulau di kota batam masuk ke FTZ. Lalu munculnya pemberlakuan PPN dan PPnBM di Kota Batam yang berbatasan dengan Singapura dan Malaysia itu juga otomatis akan menghilangkan keistimewaan Batam yang selama ini mendapatkan perlakuan istimewa sebagai lokomotif perekonomian Indonesia.

"Bila daerah yang masuk KEK ditetapkan, maka daerah di luar KEK harus dikenakan PPN (Pajak Pertambahan Nilai) dan PPnBM (Pajak Penjualan atas Barang Mewah). Tentu saja, semua barang-barang di Batam akan naik lagi, yang kena tentu adalah pengusaha dan masyarakat. Itu adalah fakta. Dulu kami perjuangankan habishabisan demi penghapusan PPN dan PPnBM di Batam, sekarang keistimewaan itu akan dicabut lagi. tu pun hanya untuk perusahaan yang baru masuk dan nilai investasinya harus diatas Rp500 miliar. Lalu, kapan kami pengusaha lokal dan masyarakat menikmati itu?. (CNN Indonesia).

Dampak penolakan sejumlah pengusaha kota batam ini justru tidak adanya keharmonisan antara pemerintah kota batam dan pengusaha kota batam dalam mencari win-win solusion agar munculnya rasa optimisme pengusaha bersama pemerintah kota batam dalam merujuk ke kolaborasi dengan ketentuan yang tidak melanggar hukum berdasarkan peraturan daerah supaya meskipun menuai pro dan kontra, kelangsungan investasi dalam negeri baik luar negeri bisa sesuai keinginan masyarakat yang berdampak dan meningkatnya perekonomian di kota batam.

\section{Kelemahan dan Keuntungan KEK Kota Batam}


KEK Kota Batam pada dasarnya mempunyai kelemahan dan keuntungan yang berdampak dalam kehidupan masyarakat Kota Batam. Berikut ini tabel perbandingan kelemahan dan keuntungan KEK di Kota Batam :

Tabel 1.

Kelemahan dan Ke untungan Kawasan Ekonomi Khusus (KEK) Di Kota Batam

\begin{tabular}{|c|c|c|}
\hline NO & Kelemahan & Keuntungan \\
\hline 1. & $\begin{array}{l}\text { Adanya peningkatan polusi dan } \\
\text { limbah yang berasal dari aktivitas } \\
\text { pabrik tentunya berdampak buruk } \\
\text { terhadap kesehatan masyarakat } \\
\text { dengan adanya keluhan sesak nafas } \\
\text { (Asma), serta membuat kawasan } \\
\text { menjadi kumuh akibat pencemaran } \\
\text { limbah. }\end{array}$ & $\begin{array}{l}\text { Mengurangi jumlah pengangguran dan } \\
\text { menyediakan lapangan pekerjaan dalam } \\
\text { jumlah besar sehingga menyerap tenaga } \\
\text { kerja. Optimisme ini muncul karena Kota } \\
\text { Batam memiliki wilayah strategis } \\
\text { berdekatan dengan negara seperti } \\
\text { singapura, malaysia yang akan melakukan } \\
\text { investor secara besar-besaran terhadap KEK } \\
\text { Kota batam. }\end{array}$ \\
\hline 2. & $\begin{array}{l}\text { Adanya ketergantungan antara } \\
\text { Pemerintah Kota Batam dan investor } \\
\text { asing yang menyebabkan KEK } \\
\text { mempunyai otoritas yang besar } \\
\text { sehingga nantinya sulit untuk keluar } \\
\text { dari persaingan global yang } \\
\text { menekankan KEK. Akibatnya, } \\
\text { pemerintah tidak bisa memiliki } \\
\text { kemampuan mengelola secara } \\
\text { mandiri di sektor industri secara } \\
\text { umum. }\end{array}$ & $\begin{array}{l}\text { Meningkatkan daya beli masyarakat dengan } \\
\text { terserapnya tenaga kerja di masyarakat } \\
\text { berdampak pada meningkatnya income } \\
\text { perkapita. }\end{array}$ \\
\hline 3. & $\begin{array}{l}\text { KEK sangat berupaya memiliki dan } \\
\text { mengelola serta menguasai bahan } \\
\text { mentah yang di ekspolitasi besar- } \\
\text { besaran, dampaknya tidak ada upaya } \\
\text { controling dalam menjaga } \\
\text { enviromental ethic. }\end{array}$ & $\begin{array}{l}\text { Perdagangan barang dan jasa akan } \\
\text { mengalami kemajuan akibat kegiatan sektor } \\
\text { ekonomi yang nyata. }\end{array}$ \\
\hline 4. & $\begin{array}{l}\text { KEK akan menjadi tokoh utama } \\
\text { dalam pasar market dengan strategi } \\
\text { monopoli baik penjual maupun } \\
\text { pembeli sehingga masyarakat kurang } \\
\text { dilibatkan dalam manajemen } \\
\text { strategis di KEK. }\end{array}$ & $\begin{array}{l}\text { Aktivitas industri dan perdagangan seperti } \\
\text { hasil produksi pertanian, perkebunan, } \\
\text { kerajinan, perikanan yang diolah sebagai } \\
\text { bahan mentah industri di KEK Batam. }\end{array}$ \\
\hline 5. & $\begin{array}{l}\text { KEK akan menjadi prioritas utama } \\
\text { dalam pasar market dengan strategi } \\
\text { monopoli baik penjual maupun } \\
\text { pembeli sehingga masyarakat kurang } \\
\text { dilibatkan dalam manajemen } \\
\text { strategis di KEK. }\end{array}$ & $\begin{array}{l}\text { Dengan adanya pasar penampungan hasil- } \\
\text { hasil pertanian, perkebunan, Dengan } \\
\text { berkembangnya kegiatan KEK, diharapkan } \\
\text { akan mendorong perkembangan industri } \\
\text { jasa pendukung lainnya yang menjadi usaha } \\
\text { masyarakat sekitar, misalnya jasa } \\
\text { angkutan, jasa pelayanan penginapan, jasa } \\
\text { hiburan, perhotelan dan lain-lain. }\end{array}$ \\
\hline 6. & $\begin{array}{l}\text { Politisasi KEK Batam oleh pemko } \\
\text { batam yang akan menguntungkan } \\
\text { penguasa dalam pengambilan } \\
\text { keputusan strategis tanpa peran BP } \\
\text { Batam yang mengendepankan } \\
\text { kepentingan politis ketimbang } \\
\text { kepentingan ekonomi. }\end{array}$ & $\begin{array}{l}\text { Pelayanan terhadap KEK melewati satu } \\
\text { pintu yaitu terhadap pemko Batam }\end{array}$ \\
\hline 7. & $\begin{array}{l}\text { KEK tidak menyeluruh di Pulau } \\
\text { Batam berbeda dengan FTZ berlaku } \\
\text { secara menyeluruh. }\end{array}$ & $\begin{array}{l}\text { KEK Batam hanya ditentukan wilayah yang } \\
\text { strategis }\end{array}$ \\
\hline
\end{tabular}

Sumber : Data Olahan Peneliti 2020 
Pada dasarnya KEK dibenttu untuk membuat lingkungan kondusif bagi aktivitasi investasi, ekspor dan perdagangan guna mendorong meningkatnya perekonomian serta katalis reformasi ekonomi pada umumnya. Keberhasilan KEK ini mengadopsi dari beberapa negara di Asia dengan tada empiris menunjukan bahwa KEK di beberapa negara tersebut mampu menarik para investor daerah dan investor asing terutama investor asing untuk berinvestasi dan menciptakan lapangan kerja. Hal itu tak lain karena kemudahan yang didapat para investor, kemudahan itu berbentuk kemudahan di bidang fiskal, perpajakan dan kewenangannya. Bahkan ada juga di bidang non-fiskal, seperti kemudahan birokrasi, pengaturan khusus di bidang ketenagakerjaan dan keimigrasian, serta pelayanan yang efisien dan ketertiban di dalam kawasan.

\section{Kesimpulan Dan Saran}

Terlepas dari kekhawatiran KEK Kota Batam, Pada kesimpulan serta saranya dari penulis bahwsananya KEK tetap menjadi perhatian utama bagi para pembuat kebijakan industri dan investasi, karena sejumlah alasan pemerintah daerah maupun pusat yaitu :

a. Pertama, relatif mudahnya mengimplementasikan reformasi bisnis melalui KEK Batam. Di negara-negara dimana tata kelola relatif lemah dan di mana implementasi reformasi secara nasional yang sulit, KEK sering dipandang sebagai satu-satunya pilihan yang layak atau sebagai langkah yang utama. Namun negara-negara berkembang yang telah membuat kemajuan menuju iklim investasi yang lebih menarik juga terus mengandalkan KEK. Ketika kemajuan tersebut gagal memberikan peringkat daya saing yang lebih baik atau investasi asing yang diharapkan, KEK mungkin masih dipandang sebagai pelengkap yang diperlukan untuk paket promosi investasi dan sebagai sinyal kemajuan negara dalam membangun serta membuat rencana strategis demi menarik iklim investasi.

b. Kedua, biaya yang dirasa rendah untuk mendirikan KEK. Alasan utama KEK adalah biaya yang relatif rendah dalam hal relatif, dibandingkan dengan membangun infrastruktur industri yang setara diseluruh sektor ekonomi. Tetapi bahkan secara nyata, biaya investasi dimuka dapat 
ditampung. Pengeluaran modal untuk pengembangan KEK terutama menawarkan bidang tanah dari pada kawasan "plug-and-play" yang hiper-modern seringkali terbatas pada koneksi infrastruktur dasar ke batas KEK. Lanjut Biaya tambahan yang sebagian besar diserahkan kepada perusahaan pengembang swasta, kemudian dikeluarkan secara bertahap ketika zona tersebut menarik investor dan mengembangkan plot individu dengan biaya pengembangan serta biaya layanan umum di kawasan KEK yang terjangkau.

c. Ketiga, meningkatnya tekanan kompetitif. KEK akan berdampak didaerah yang memiliki potensi akan menarik investasi sebagai pencari kemudahan dalam berinvestasi dalam skala internasional, dimana negara akan bersaing menanamkan modalnya. Meskipun munculnya bentuk-bentuk kawasan baru yang terkait dengan pemberdayaan sumber daya alam nantinya diarahkan kepada kawasan domestik memasarkan atau menargetkan kemampuan inovasi (mis., sains, teknologi tinggi atau kawasan hijau), sebagian besar KEK pada dasarnya tetap menjadi bagian dari paket promosi investasi kompetitif Negara bersama dengan bentuk insentif lainnya.

Program KEK terus berkembang khususnya di negara-negara berkembang, penting bagi para pembuat kebijakan untuk belajar dari pengalaman masa lalu dan untuk mengantisipasi implikasi dari masalah yang muncul dan masa yang akan datang perlu dibahas bagi penelitipeneliti selanjutnya. Upaya menarik investasi dan menciptakan lapangan kerja, memfasilitasi manfaat yang mudah, dan memastikan keberlanjutan, tulisan ini juga menetapkan sejumlah prinsip utama yang perlu dipertimbangkan oleh pembuat kebijakan. Tidak perlu menyebutkan prinsip-prinsip secaara terperinci namun perlu diketahui bahwa mencapai keberhasilan pada program KEK di masa depan akan memerlukan dengan cara mengadopsi pendekatan yang lebih fleksibel untuk menggunakan instrumen KEK dengan cara yang paling efektif untuk memanfaatkan sumber daya alam dan sumber daya manusia atas keunggulan komparatif suatu wiayah KEK. Demi terciptanya fleksibilitas untuk memungkinkan evolusi program KEK dari waktu ke waktu.

Yang paling mendasar, KEK akan membutuhkan perubahan pola pikir dari ketergantungan yang menjadi kebiasaan lama pada insentif 
pembebasan pajak dan pengaturan upah kerja, dan sebaliknya berfokus pada memfasilitasi lingkungan yang lebih efektif untuk mendorong daya saing pada tingkat perusahaan, integrasi ekonomi lokal, inovasi, dan sosial dan ketahanan lingkungan. Ini juga akan memerlukan pendekatan kebijakan yang proaktif, fleksibel, dan inovatif untuk mengatasi kendala makro ekonomi yang terjadi saat ini dan banyak tantangan yang tidak terduga yang akan membentuk lingkungan di tahun-tahun mendatang.

\section{DAFTAR PUSTAKA}

Abrahamson, E. (2000). Change without pain. Harvard Business Review, 78(4), 75-79.

Aggarwal, A. (2007). Impact of Special Economic Zones on Employment, Poverty and Human Development (No. 194). New Delhi, India.

Daft, R. L., \& Daft, R. L. (2010). Understanding the theory and design of organizations (11th ed.). United States America: South-Western, Cengage Learning.

David, D. (2005). A Multilevel approach to individual readiness to change. Journal of Behavioral and Applied Management, 7(1), 1-15.

Farole, T., \& Akinci, G. (2011). Special Economic Zones: Progress, Emerging Challenges and Future Directions. Directionsin Developmen Trade. Washington DC: The World Bank.

Internasional Labour Organization. (1998). Labour and social issues relating to eport processing zones. Geneva.

Kusago, T., \& Tzannatos, Z. (1998). Export processing zones: A review in need of update. Social Protection Discussion No. 9802.

Madani, D. (1999). A review of the role and impact of export processing zones. Research Working Paper, 1(1).

Moberg, L. (2015). The political economy of special economic zones. Journal of Institutional Economics, 11(1), 167-190.

Porras, J. I., \& Robertson, P. J. (1992). Organizational development: Theory, practice, and research. California: Consulting Psychologists Press.

Pramoda, R., \& Apriliani, T. (2016). Kebijakan Penetapan Bitung Sebagai Kawasan Ekonomi Khusus (KEK). Jurnal Borneo Administrator, 12(2), 149-169.

Thurston, C. W. (1996). Argentina plans to develop network of free trade zones. Retrieved January 18, 2020, from https://www.joc.com/maritimenews/argentina-plans-develop-network-free-trade-zones_19960618.html

United Nations Conference On Trade And Development. (2019). World 
Investment Report. In Special Economic Zones (pp. 127-206). Geneva.

Valentine, V., \& Park, J. K. (2005). Free trade zone and port hinterland development. New York: United Nations Publication.

World Bank. (1992). The world bank annual report 1992. Washington DC.

Zed, M. (2014). Metode penelitian kepustakaan (3rd ed.). Jakarta: Yayasan Obor Indonesia.

\section{Dokumen}

Undang-Undang Nomor 1 Tahun 2007 tentang Kawasan Perdagangan Bebas

Undang-Undang Nomor 36 Tahun 2000 tentang Penetapan Peraturan Pemerintah Pengganti Undang-Undang Nomor 1 Tahun 2000 tentang Kawasan Perdagangan Bebas dan Pelabuhan Bebas Menjadi UndangUndang

\section{Website}

Pengusaha Tolak Batam Jadi KEK (n.d.). Diperoleh pada Januari 18, 2020, dari https://www.cnnindonesia.com/ekonomi/20180604085527-92303165/pengusaha-tolak-batam-jadi-kawasan-ekonomi-khusus

Pembentukan Batam menjadi Kawasan Ekonomi Khusus (n.d.). Diperoleh pada Januari 22, 2020, dari https://www.straitstimes.com/asia/seasia/turning-batam-into-a-special-economic-zone-the-jakarta-post

Perubahan Kepemimpinan terhadap status KEK Batam (n.d.). Diperoleh pada Januari 22, 2020, dari https://www.straitstimes.com/asia/seasia/changes-in-bp-batam-oversight-could-lead-to-islands-sez-status

Jokowi Pembubaran BP Batam (n.d.). Diperoleh pada Maret 3, 2020, dari https://www.cnbcindonesia.com/news/20181212182657-446116/jokowi-pembubaran-bp-batam-dan-singapuranya-indonesia/2 